\title{
Basic Competence of Intensive Care Unit Nurses: Cross-Sectional Survey Study
}

\author{
Riitta-Liisa Lakanmaa, ${ }^{1}$ Tarja Suominen, ${ }^{2}$ Marita Ritmala-Castrén, ${ }^{3}$ \\ Tero Vahlberg, ${ }^{4}$ and Helena Leino-Kilpi ${ }^{5,6}$ \\ ${ }^{1}$ Turku University of Applied Sciences, 20720 Turku, Finland \\ ${ }^{2}$ School of Health Sciences, University of Tampere and University of Turku, 33014 Tampere, Finland \\ ${ }^{3}$ Department of Anesthesiology and Intensive Care, Helsinki University Hospital, HUS, 00029 Helsinki, Finland \\ ${ }^{4}$ Biostatistics, University of Turku, 20014 Turku, Finland \\ ${ }^{5}$ Department of Nursing Science, University of Turku, 20014 Turku, Finland \\ ${ }^{6}$ Turku University Hospital, 20521 Turku, Finland
}

Correspondence should be addressed to Riitta-Liisa Lakanmaa; riitta-liisa.lakanmaa@turkuamk.fi

Received 28 December 2014; Accepted 23 April 2015

Academic Editor: Elizabeth Papathanassoglou

Copyright (C) 2015 Riitta-Liisa Lakanmaa et al. This is an open access article distributed under the Creative Commons Attribution License, which permits unrestricted use, distribution, and reproduction in any medium, provided the original work is properly cited.

Critical care patients benefit from the attention of nursing personnel with a high competence level. The aim of the study was to describe and evaluate the self-assessed basic competence of intensive care unit nurses and related factors. A cross-sectional survey design was used. A basic competence scale (Intensive and Critical Care Nursing Competence Scale version 1, Likert scale 1-5, 1 $=$ poor and $5=$ excellent) was employed among Finnish intensive care unit nurses $(n=431)$. Intensive care unit nurses' selfassessed basic competence was good (mean 4.19, SD 0.40). The attitude and value base of basic competence was excellent whereas experience base was the poorest compared to the knowledge base and skill base of intensive and critical care nursing. The strongest factor explaining nurses' basic competence was their experience of autonomy in nursing care ( $F$ value $60.85, \beta 0.11, \mathrm{SE} 0.01$, and $P \leq 0.0001)$. Clinical competence was self-rated as good. Nurses gave their highest competence self-ratings for ICU patient care according to the principles of nursing care. The ICU nurses also self-rated their professional competence as good. Collaboration was self-rated as the best competence. In basic and continuing education and professional self-development discussions it is meaningful to consider and find solutions for how to improve nurses' experienced autonomy in nursing.

\section{Introduction}

What is known about this topic?

(i) Competence in intensive and critical care nursing (ICCN) is a multidimensional concept.

(ii) There are, globally, definitions and descriptions of competence in ICCN but only a few studies of intensive care unit nurses' competence.

(iii) Competence evaluation in ICCN education and practice is essential for the nurses' professional development.
What does this paper add?

(i) Intensive care unit (ICU) nurses' competence contains four bases: knowledge base, skill base, attitude and value base, and experience base. ICU nurses selfevaluated their experience base as the poorest. Experience of ICCN care is crucial for the professional development of the ICU nurses.

(ii) ICU nurses' experience of autonomy in nursing care explains self-evaluated basic competence. Autonomy in nursing care is important for the professional growth of the ICU nurses. 
(iii) Comprehensive competence of ICU nurses should in various ways be developed during ICCN education and orientation programs. This should be considered carefully when planning the contents and educational methods for the programs.

There are approximately 30 intensive care units (ICUs) in Finland in which over 28,000 patients are cared for annually [1]. It is estimated that by the year 2030 the need for intensive and critical care will grow by $25 \%$, for example, due to the fact that the Finnish population is getting older [2]. Multifactorial reasons increase the need of critical care beds in Finland and also in other countries in Europe.

Intensive care unit nurses (ICU nurses) are the largest professional group working in the ICUs. Severely ill patients and families benefit from the attention of highly trained and skilled personnel $[3,4]$. ICU nurses contribute to patient safety, such as improved patient outcomes, reduced morbidity and mortality, and decreased complications, errors, and overall costs [5-10]. Competent ICU nurses have a significant impact on ICU patient's physiological and psychological outcomes, for example, evidence based nursing interventions and ethical activity.

Critical care nursing is an own nursing speciality [11] whereas technology is integrated with psychosocial challenges and ethical conflicts associated with critical illness [12]. Generally, critical care nursing education is a special postqualification education [13] and is described in the European Qualifications Framework for Lifelong Learning as level 6 (of eight) $[14,15]$. Currently no postqualification education in intensive and critical care nursing leading to a degree exists in Finland.

We know that there is a worldwide need for competent nurses [16]. In nursing practice, nurses get to demonstrate on a regular basis clinical competence as well as a sound theoretical knowledge base according to nationally recognized frameworks $[4,17,18]$. There is a need for valid specific instruments (e.g., for intensive and critical care nursing) for competence evaluation purposes. Competence evaluation can be performed in various ways, for example, using self-assessment, knowledge tests, peer evaluation (colleague), observation (mentor, supervisor), OSCE (objective structured clinical examination), or portfolios. The best way to perform competence evaluation is to combine different evaluation methods. Self-assessment is an essential ability that can be learned and developed during education and nursing career.

Intensive and Critical Care Nursing Competence Scale research is scarce. Only three scales (Basic Knowledge Assessment Tool [BKAT], Intensive Care Hundred Item Test [IHIT], and multilevelled critical care competency statements) of competence in intensive and critical care nursing are reported in nursing literature [19]. Of these scales, two are knowledge tests (BKAT + I-HIT) while the third one is based on nurses' self-assessment; however, we are well aware that it has not been properly tested for reliability and validity and is still in its early phases. The need for a basic competence self-assessment scale in intensive and critical care nursing is therefore also evident, for example, for undergraduate education for beginning registered nurses practice standards. The systematic literature review conducted for this study in PubMed and search from critical care nursing organizations over the last ten years found 21 studies or documents of competence in intensive and critical care nursing (see the appendix).

As a summary of the literature, competence concept is very multidimensional (e.g., focusing on clinical practice [nursing process], ethics, collaboration, leadership, education, and development work) and strongly related to, for example, age, work experience, and frequency of using specific competencies. Competence is studied worldwide (10 documents from Europe, 7 documents from Australia and New Zealand, and 4 documents from USA, Canada, and Brazil); thus, there is lacking systematic competence evaluation research. Evaluation is often performed by selfassessment [20-22] or knowledge test [23]. ICU nurses' selfassessed competence was evaluated as ranging from moderate to excellent: from moderate to good (sample consisting of newly registered ICU nurses) [22], good (sample consisting of ICU nurses with varying work experience) [20], and from good to excellent (sample consisting of ICU nurses with varying work experience) [21]. European ICU nurses' overall knowledge score was $66 \%$ of 100 points $(\min 22, \max 91$, and SD 12); the main factor that contributed to variance in scores is length of nurses' intensive care experience. The knowledge category with the lowest score was respiration and ventilation [23].

The purpose of this empirical study was to describe and evaluate the self-assessed basic competence of intensive care unit nurses and related factors using a scale, Intensive and Critical Care Nursing Competence Scale version 1 (ICCNCS-1) [11]. The related factors were divided into the following areas: (i) age and gender, (ii) education, (iii) work experience, (iv) information retrieval, (v) knowledge test, and (vi) others. The hypothesis was that the basic competence can be explained with these. This empirical study is part of a larger project where the scale was developed [19]. This study was conducted to facilitate establishment of the psychometric properties (reliability and construct validity) of the scale being used [24]. The project from which this study is a part aimed to define competence in intensive and critical care nursing (ICCN), to develop a basic self-assessment based measurement scale for competence evaluation in ICCN, and to describe graduating nursing students' basic competence in ICCN by seeking reference basis from ICU nurses.

ICU nurse is a registered nurse who practises in an ICU and whose nurse education is Bachelor of Health Care, specialist nurse, or nurse. In this ICU nurses basic competence study was used also the experience base of the ICU nurses in data analysis which were not analysed in graduating nursing students' basic competence study. The students had no experience base enough in ICCN and therefore in data analysis only three bases of four were analysed knowledge, skill, and attitude and value bases. A novel issue in this study is that it highlights the multidimensionality of the concept of competence. Four bases of competence in intensive and critical care nursing were analysed in ICU nurses' data: knowledge base, skill base, attitude and value base, and experience base [19]. 
TABLE 1: Structure and item amounts of ICCN-CS-1.

\begin{tabular}{|c|c|c|c|c|c|}
\hline $\begin{array}{l}\text { Basic competence }=\text { clinical competence }+ \text { professional } \\
\text { competence }\end{array}$ & $\begin{array}{l}\text { Knowledge } \\
\text { base }\end{array}$ & $\begin{array}{l}\text { Skill } \\
\text { base }\end{array}$ & $\begin{array}{l}\text { Attitude and } \\
\text { value base }\end{array}$ & $\begin{array}{l}\text { Experience } \\
\text { base }\end{array}$ & Items \\
\hline \multicolumn{6}{|l|}{ Clinical competence (80) } \\
\hline Principles of nursing care & 4 & 4 & 4 & 4 & 16 \\
\hline Clinical guidelines & 4 & 4 & 4 & 4 & 16 \\
\hline Nursing interventions & 12 & 12 & 12 & 12 & 48 \\
\hline \multicolumn{6}{|l|}{ Professional competence (64) } \\
\hline Ethical activity and familiarity with health care laws & 4 & 4 & 4 & 4 & 16 \\
\hline Decision-making & 4 & 4 & 4 & 4 & 16 \\
\hline Development work & 4 & 4 & 4 & 4 & 16 \\
\hline Collaboration & 4 & 4 & 4 & 4 & 16 \\
\hline Items & 36 & 36 & 36 & 36 & 144 \\
\hline
\end{tabular}

ICCN-CS-1 measures basic competence and it refers to preliminary competence to practice in an ICU. It is comparable to step 1 competencies of the National Competency Framework for Adult Critical Care Nurses [25] and Critical Care Nurse Education Practice Standards [26]. ICCNCS-1 is useful in planning supervision in preregistration nursing students' clinical practice and during orientation programmes, for example, to identify learning gaps, define learning goals, and discuss competence in a comprehensive manner. The content of the scale is in line with postgraduate education standards and the competence standards of critical care nurses, also at specialist level. The scale measures the basic competence in intensive and critical care nursing and can be used as a starting point for the transition process from preregistration education to postgraduation education. The scale was developed for intensive and critical care education purposes, for example, for preregistration education and in orientation programmes. The results of this study can be useful in nursing education, especially in basic education and when planning continuous education. In clinical practice the results can also be helpful in professional performance appraisals in ICUs.

\section{Materials and Methods}

2.1. Aim. The aim of the study was to describe and evaluate the self-assessed basic competence of intensive care unit nurses and related factors. The results of this study will help educators, clinicians, and researchers to develop basic nursing education and orientation in the ICUs.

2.2. Research Questions. The research questions for this study were as follows:

(1) What is the level of intensive care unit nurses' selfassessed basic competence?

(2) What are factors related to the basic competence?

2.3. Design. A cross-sectional survey design was employed using questionnaires among Finnish ICU nurses in university hospitals.
2.4. Sample/Participants. Total sampling was used for ICU nurses in five Finnish university hospitals $(n=431$ participants, response rate $54 \%$ ). In one of the five university hospitals, a convenience sample of ICU nurses $(n=82$ participants, response rate $37 \%$ ) also completed a biological and physiological knowledge test. In 2008, a pilot study had been conducted in one university hospital; this organization was therefore not included in this data gathering in 2010. The final number of hospitals taking part in this study was thus four.

2.5. Data Collection. Data were collected using a questionnaire with the support of contact persons in the ICUs. The instruments used in this study were the Intensive and Critical Care Nursing Competence Scale (ICCN-CS-1) [24] and a knowledge test, the Basic Knowledge Assessment Tool version 7 (=BKAT-7) [27], which was used as the background factor in the convenience sample. Background factors (12) integral to the ICCN-CS-1 were asked and they formed the first page of the questionnaire.

ICCN-CS-1 is a self-assessment tool consisting of 144 items (six sum variables). The scale measures basic competence in intensive and critical care nursing. Theoretically, basic competence is divided into clinical competence and professional competence. Clinical competence consists of three subdomains: principles of nursing care, clinical guidelines, and nursing interventions. Professional competence consists of four subdomains: ethical activity and familiarity with health care laws, decision-making, development work, and collaboration. In addition, basic competence comprises four bases: knowledge, skill, attitude and value, and experience bases. Each of them has seven subdomains. Every item is measured with the Likert scale 1-5, giving the range score 144-720. Sum of scores on the ICCN-CS-1 can be classified as poor competence (144-288), moderate competence (289432 ), good competence (433-576), or excellent competence (577-720) [24]. Mean score can be classified as follows: 1-2.49, poor; $2.5-3.49$, moderate; 3.5-4.49, good; or 4.5-5.0, excellent (Table 1) [19].

The 12 background factors for all ICU nurses were divided into five areas: (i) age and gender (2 questions), (ii) education (basic, continuing education, and participation 
in conferences; 3 questions), (iii) work experience (ICU, other health care; 2 questions), (iv) information retrieval (independent, use of nursing journals; 2 questions), and (v) others (autonomy in nursing and work motivation, on scale $1-10,1=$ poor and $10=$ excellent, and special responsibility areas in ICU, scale yes/no). The respondents' experience of autonomy in nursing was asked by requesting them to assess how autonomous they felt their work as a nurse. The convenience sample of ICU nurses $(n=82)$ completed the BKAT-7 as an extra background factor area (vi). BKAT-7 is a biological and physiological knowledge test comprising 100 items. Each correct answer gives one point, yielding the range 0-100. The BKAT has eight sum variables: cardiovascular, monitoring lines, pulmonary, neurology, endocrine, renal, gastrointestinal, and other variables [27]. The data were gathered between January 2010 and May 2010.

2.6. Ethical Considerations. The research was conducted according to ethical guidelines [28, 29]. Ethics committee approval was obtained from a university XXX [26.10.2009]. The permission to use BKAT-7 was given by Dr. Jean Toth and to use the Finnish version by MNSc MaritaRitmalaCastrén. Research permission was obtained separately from each participating hospital. Participation was voluntary and based on anonymity in every phase. It was assumed that by returning the questionnaire participants gave their consent to take part in the study. The hospitals were not compared with each other. The data were stored according to ethical guidelines (in safe storage and anonymously).

2.7. Data Analysis. The data were statistically analysed using SAS for Windows (version 9.2, SAS Institute Inc., Cary, NC). The sum variables were calculated by dividing the sum score by the number of items answered. To calculate the sum variables and total sum of the ICCN-CS-1 and BKAT$7,80 \%$ of the items should be answered. Two-independentsample $t$-test was used to test the differences in basic competence between factors that consisted of two categories. The difference in basic competence between education groups was tested with one-way analysis of variance using Tukey's adjustment in pairwise comparisons. Linear associations between continuous background factors and basic competence were analysed using linear regression analysis. Factors associated with basic competence were included in analysis of covariance, except for age which was excluded to avoid multicollinearity problems (age versus work experience, $r=$ 0.76), while other work experience was excluded due to the high number of missing values $(n=103)$. Correlations were calculated using the Spearman correlation coefficients. The level of statistical significance was defined as $P<0.05$.

2.8. Validity and Reliability. Reliability and validity of the ICCN-CS-1 have been tested and were shown to be adequate for the scale at its early stage. The scale is based on an extensive theoretical phase where the content of competence was defined [24]. In this study the internal consistency of ICCN-CS-1 was 0.99 (range of sum variables 0.88-0.98), which showed adequate reliability. The reliability and validity of the scale need further developing and testing. As the BKAT is a knowledge test, its internal consistency was not evaluated.

\section{Results}

3.1. Participants. Most participants were female (84.6\%) and their mean age was 38 years (range 22-62). Most of the nurses had a Bachelor of Health Care degree (52.9\%) and their mean length of work experience in ICU was 9.1 years (0.02-36 years) (Table 2).

3.2. ICU Nurses' Basic Competence. The nurses' $(n=431)$ self-rated basic competence was $67.5 \%$ excellent, $32.3 \%$ good, and $0.2 \%$ moderate. The mean score was 4.19 (2.79-5.00, SD 0.40). Clinical competence (directly related to patient care) was self-rated as good. Nurses gave their highest competence self-ratings for ICU patient care according to the principles of nursing care (this refers to ethical standards such as safety, justness, patient centeredness, recognition of abnormal vital signs, need of pain care, changes in skin condition, and need of fluid therapy). The ICU nurses self-rated their professional competence (related to the profession in general) as good. Collaboration was self-rated as the best competence and development work as the poorest. Clinical competence was rated as better than professional competence. The nurses selfrated their knowledge base, skill base, and experience base as good. Attitude and value base was rated as excellent. The nurses gave the poorest ratings for the experience base of competence (Table 3).

3.3. Background Factors in relation to Basic Competence. Of the twelve background factors ten were positively associated with basic competence (Table 4). The values obtained from univariable models, ANCOVAs, when forming ANCOVA model $(n=405)$ where age and other work experience were excluded (age and work experience were highly correlated, $r=0.76$, and other work experience had 103 missing values), autonomy in nursing care $(F$ value $60.85, \beta 0.11$, SE 0.01 , $P \leq 0.0001$ ), special responsibility areas in the ICU ( $F$ value 9.33, $\beta 0.13$, SE 0.04 , and $P=0.0024)$, work experience in ICU ( $F$ value $7.73, \beta 0.008$, SE 0.003 , and $P=0.0057$ ), independent information retrieval of intensive and critical care nursing ( $F$ value 7.07, $\beta 0.17$, SE 0.07 , and $P=0.0082$ ), and participation in intensive care conferences and education days ( $F$ value 5.78, $\beta 0.10$, SE 0.04 , and $P=0.0167$ ) remained significant. More education (basic and continuing education) and information retrieval (use of nursing journals) were positively related to basic competence, whereas work motivation or gender had a negative association with it.

A knowledge test, BKAT-7, was used as the background factor in this study in a convenience sample of ICU nurses. The ICU nurses' mean score of BKAT-7 was $(n=82)$ 68.26 (SD 10.27, range 32-86) and the ICCN-CS-1 mean score was 4.13 (SD 0.42, range 3.02-5.00). No correlation was detected between knowledge test and self-assessment basic competence scale $(r=0.098)$. 
TABLE 2: Characteristics of nurses $(n=431)$.

\begin{tabular}{|c|c|c|c|c|c|}
\hline \multirow{3}{*}{ Background factors } & \multicolumn{5}{|c|}{ Nurses } \\
\hline & Mean & SD & Min & & Max \\
\hline & \multicolumn{2}{|c|}{$n$} & \multicolumn{3}{|c|}{$\%$} \\
\hline Age $(n=430)$ & 38 & 9.9 & 22 & & 62 \\
\hline \multicolumn{6}{|l|}{ Gender $(n=421)$} \\
\hline Female/male & & & & $84.6 / 15.4$ & \\
\hline \multicolumn{6}{|l|}{ Education $(n=429)$} \\
\hline Nurse (Bachelor of Health Care) & & & & 52.9 & \\
\hline Specialist nurse & & & & 22.1 & \\
\hline Nurse & & & & 19.1 & \\
\hline Others & & & & 5.8 & \\
\hline $\begin{array}{l}\text { Work experience (years) as a nurse in intensive } \\
\text { and critical care }(n=425)\end{array}$ & 9.1 & 8.1 & 0.02 & & 36 \\
\hline $\begin{array}{l}\text { Other work experience as a nurse in health care } \\
(n=328)\end{array}$ & 5.4 & 7.2 & 0 & & 37 \\
\hline \multicolumn{6}{|l|}{$\begin{array}{l}\text { Continuing education in intensive care nursing } \\
(n=423)\end{array}$} \\
\hline Yes & & & & 17.3 & \\
\hline No & & & & 82.7 & \\
\hline \multicolumn{6}{|l|}{$\begin{array}{l}\text { Participation in intensive care conferences and } \\
\text { education days }(n=428)\end{array}$} \\
\hline Yes & & & & 71.7 & \\
\hline No & & & & 28.3 & \\
\hline \multicolumn{6}{|l|}{$\begin{array}{l}\text { Independent information retrieval of intensive } \\
\text { and critical care nursing }(n=426)\end{array}$} \\
\hline Yes & & & & 93.9 & \\
\hline No & & & & 6.1 & \\
\hline \multicolumn{6}{|l|}{$\begin{array}{l}\text { Use of nursing journals in information retrieval of } \\
\text { intensive and critical care nursing }(n=429)\end{array}$} \\
\hline Yes & & & & 86.0 & \\
\hline (i) International scientific journals & & & & 18.3 & \\
\hline (ii) National scientific journals & & & & 38.4 & \\
\hline (iii) Professional journals & & & & 95.9 & \\
\hline No & & & & 14.0 & \\
\hline Work motivation $(1-10)(n=429)$ & 8.1 & 1.5 & 2 & & 10 \\
\hline Autonomy in nursing $(1-10)(n=430)$ & 8.1 & 1.2 & 2 & & 10 \\
\hline \multicolumn{6}{|l|}{ Special responsibility areas in the ICU $(n=428)$} \\
\hline Yes & & & & 76.2 & \\
\hline No & & & & 23.8 & \\
\hline
\end{tabular}

\section{Discussion}

This study used a self-assessment based competence scale which is developed directly for intensive and critical care nursing. It is clinically important that nursing competence in specific areas of nursing is evaluated with the help of specific competence scales.

ICU nurses' self-assessed basic competence was in general good and was related to work experience as found in previous studies [20-22]. They rated their clinical competence higher than professional competence. The reason for this may be the high technical and clinical skill requirements in the ICUs. Also ethics was highlighted in many ways: ICU nurses self-assessed their attitude and value base as excellent. In clinical competence, "principles of nursing care" was rated as high while in professional competence "ethical activity and familiarity with health care laws" was rated as low. This can be explained by the fact that ICU nurses at bed-side nursing care 
TABLE 3: The domains and bases of basic competence and the self-assessment scores.

\begin{tabular}{|c|c|c|}
\hline \multirow[t]{2}{*}{ Domains and bases of basic competence } & \multicolumn{2}{|c|}{$\begin{array}{l}\text { Self-assessment scores }(1-5) \\
\qquad(n=428-431)\end{array}$} \\
\hline & Mean & SD \\
\hline Basic competence & 4.19 & 0.40 \\
\hline Clinical competence & 4.33 & 0.39 \\
\hline Principles of nursing care & 4.47 & 0.41 \\
\hline Clinical guidelines & 4.36 & 0.38 \\
\hline Nursing interventions & 4.27 & 0.44 \\
\hline Professional competence & 4.02 & 0.45 \\
\hline Collaboration & 4.28 & 0.45 \\
\hline Decision-making & 4.24 & 0.48 \\
\hline Ethical activity and familiarity with health care laws & 3.90 & 0.55 \\
\hline Development work & 3.65 & 0.59 \\
\hline Attitude and value base of competence & 4.68 & 0.32 \\
\hline Knowledge base of competence & 4.05 & 0.45 \\
\hline Skill base of competence & 4.02 & 0.46 \\
\hline Experience base of competence & 3.82 & 0.68 \\
\hline
\end{tabular}

are more familiar with safe, direct patient-centred care (when using in practice these competencies frequently in daily care) than with adherence to ethical codes, general health care legislation, and transplantation legislation (literally) [20-22].

In professional competence, collaboration was selfassessed as the best and development work (referring to self-development, team development, nursing development, and subordinate skill development) as the poorest dimension of competence. This finding shares similarities with several previous studies [20-22]. One reason may be that nurses lack education, experience, and resources for development work in their profession. In addition, nurses' attitudes towards evidence based nursing and development work may be negative because they do not see themselves as "developers," merely as "clinical workers." They might also think that these kinds of jobs are not for them, or they may not have enough knowledge of them.

In experience base the nurses were guided to evaluate how sufficient they assess the quality of their experience in specific issues in intensive and critical care nursing ("Do the nurses have enough experience in every aspect of competence?") The nurses regarded this with suspicion. They evaluated the quality and sufficiency of their experience base very critically. The researchers interpreted this as denoting that special competence in nursing is associated with extensive experience. The autonomy in nursing experienced by nurses was the strongest factor related to basic competence. This finding is logical and natural because autonomy is an essential element of professional status as stated by Varjus et al. in their review [30].

The basic biological and physiological knowledge did not correlate with self-assessed basic competence. In this study the ICU nurses' mean of BKAT-7 knowledge test was 68 of 100 (SD 10), which correlates to a previous study by Fulbrook et al. [23] (Finnish nurses' mean score was 64 of 100, SD
9; in this European ICU nurses study, the I-HIT knowledge test was used). Competence as a concept is holistic and multidimensional, with knowledge only a part of the whole. This gives an idea for competence evaluation and planning in nursing education. "Knowledge base comes first," but also other fields of competence such as skill base, attitude and value base, and experience base as well as personal base of the ICU nurse are important [11].

Most of the ICU nurses search for information independently and participate in conferences and education days. The variance in work motivation and autonomy in nursing was $2-10$, which means that some nurses have very low motivation and do not feel autonomy in their work. In this study, work motivation was not associated with self-assessed basic competence whereas autonomy was strongly associated with it. It is important that the relationship between "safety culture" and "basic competence" is examined together and attended to in ICUs. Nurses' competence is related to intent to leave nursing profession, job satisfaction, patient safety, and quality of nursing in ICUs [31].

4.1. Strengths and Limitations. There are limitations in this study. They are related to the national sample, sampling which covered only university hospitals and the somewhat low response rate. The basic competence scale ICCN-CS-1 was a new scale and it shares the same difficulties with a previous holistic competence scale developed for critical care nursing [32]. The Cronbach alpha values were somewhat high and the nature of the competence scale is unidimensional, and the items correlate strongly with each other [19]. Furthermore, the method of self-assessment is questionable: how reliable is self-assessment as a method? Self-assessment as a skill is important for nurses; however, it should not be used alone but in combination with other assessment methods. It is also important to recognize the bias related to respondents. 
TABLE 4: Statistically significant background factors in relation to basic competence.

\begin{tabular}{|c|c|c|c|c|c|}
\hline Background factor & $P$ value & Regression coefficient $\beta$ & Standard error & Mean of ICCN-CS-1 & $\mathrm{SD}$ \\
\hline Age $(n=430)$ & $<0.0001^{1}$ & 0.02 & 0.002 & & \\
\hline Education $(n=429)$ & $<0.0001^{2}$ & & & & \\
\hline Nurse (Bachelor of Health Care) & & & & 4.07 & 0.38 \\
\hline Specialist nurse & & & & 4.39 & 0.32 \\
\hline Nurse & & & & 4.35 & 0.36 \\
\hline Others & & & & 4.04 & 0.43 \\
\hline $\begin{array}{l}\text { Work experience (years) as a nurse in } \\
\text { intensive and critical care }(n=425)\end{array}$ & $<0.0001^{3}$ & 0.02 & 0.002 & & \\
\hline $\begin{array}{l}\text { Other work experience as a nurse in } \\
\text { health care }(n=328)\end{array}$ & $0.0004^{1}$ & 0.01 & 0.003 & & \\
\hline $\begin{array}{l}\text { Continuing education in intensive care } \\
\text { nursing }(n=423)\end{array}$ & $<0.0001^{3}$ & & & & \\
\hline Yes & & & & 4.35 & 0.40 \\
\hline No & & & & 4.15 & 0.39 \\
\hline $\begin{array}{l}\text { Participation in intensive care } \\
\text { conferences and education days }(n=428)\end{array}$ & $<0.0001^{3}$ & & & & \\
\hline Yes & & & & 4.30 & 0.35 \\
\hline No & & & & 3.92 & 0.39 \\
\hline $\begin{array}{l}\text { Independent information retrieval of } \\
\text { intensive and critical care nursing } \\
(n=426)\end{array}$ & $0.0001^{3}$ & & & & \\
\hline Yes & & & & 4.21 & 0.39 \\
\hline No & & & & 3.90 & 0.43 \\
\hline Use of nursing journals $(n=429)$ & $<0.0001^{3}$ & & & & \\
\hline Yes & & & & 4.23 & 0.38 \\
\hline No & & & & 4.00 & 0.43 \\
\hline $\begin{array}{l}\text { Autonomy in nursing care }(1-10) \\
(n=429)\end{array}$ & $<0.0001^{1}$ & 0.16 & 0.01 & & \\
\hline $\begin{array}{l}\text { Special responsibility areas in the ICU } \\
(n=428)\end{array}$ & $<0.0001^{3}$ & & & & \\
\hline Yes & & & & 4.28 & 0.36 \\
\hline No & & & & 3.90 & 0.39 \\
\hline
\end{tabular}

Dropout analysis was not performed. However, the scale was developed very carefully by experts in an academic setting and the sampling was planned to cover the most competencedemanding ICUs in Finland. The response rate was also quite good for a questionnaire study.

\section{Conclusions}

Firstly, ICU nurses' experienced autonomy in nursing care is highly related to self-assessed basic competence. Secondly, specific responsibility areas in ICUs (such as medical emergency team member, student supervisor) and, thirdly, work experience in the ICU are related to self-assessed basic competence. In basic and continuing education and professional self-development discussions it is meaningful to consider and find solutions for how to improve nurses' experienced autonomy in nursing and how to find specific interest areas for every ICU nurse and motivate as well as retain them in intensive and critical care nursing. Fourthly, work experience in years as well as the quality of work experience (sufficiency) is an essential part of basic competence in intensive and critical care nursing. Fifthly, there are domains in ICU nurses' basic competence that score lower than other domains and bases, such as "experience base of competence," "development work," and "ethical activity and familiarity with health care laws," which can be highlighted in education planning.

\section{Appendix}

See Table 5. 
TABLE 5: Summary of competence literature in intensive and critical care nursing 2004-2014.

\begin{tabular}{|c|c|c|c|}
\hline $\begin{array}{l}\text { Organisation/author, } \\
\text { year, country }\end{array}$ & $\begin{array}{l}\text { Document/title of the } \\
\text { study/method }\end{array}$ & Aim & Main findings/results \\
\hline $\begin{array}{l}\text { Gill et al. 2015, } \\
\text { Australia [26] }\end{array}$ & $\begin{array}{l}\text { "Development of } \\
\text { Australian Clinical Practice } \\
\text { Outcome Standards for } \\
\text { Graduates of Critical Care } \\
\text { Nurse Education" } \\
\text { Delphi technique }\end{array}$ & $\begin{array}{l}\text { To develop critical care } \\
\text { nurse education practice } \\
\text { standards }\end{array}$ & $\begin{array}{l}\text { The process resulted in the development of } \\
98 \text { practice standards, categorized into three } \\
\text { levels }\end{array}$ \\
\hline $\begin{array}{l}\text { Lakanmaa et al. 2014, } \\
\text { Finland [24] }\end{array}$ & $\begin{array}{l}\text { "Basic Competence in } \\
\text { Intensive and Critical Care } \\
\text { Nursing: Development and } \\
\text { Psychometric Testing of a } \\
\text { Competence Scale" } \\
\text { Questionnaire survey }\end{array}$ & $\begin{array}{l}\text { To develop a scale to assess } \\
\text { basic competence in } \\
\text { intensive and critical care } \\
\text { nursing }\end{array}$ & $\begin{array}{l}\text { The Intensive and Critical Care Nursing } \\
\text { Competence Scale is a self-assessment test } \\
\text { consisting of } 144 \text { items. Basic competence is } \\
\text { divided into patient-related clinical } \\
\text { competence and general professional } \\
\text { competence. Basic competence consists of } \\
\text { knowledge base, skill base, attitude and } \\
\text { value base, and experience base }\end{array}$ \\
\hline $\begin{array}{l}\text { EfCCNa 2013, } \\
\text { Europe [4] }\end{array}$ & $\begin{array}{l}\text { "EfCCNa Competencies for } \\
\text { European Critical Care } \\
\text { Nurses" }\end{array}$ & $\begin{array}{l}\text { To develop a European } \\
\text { Critical Care Nursing } \\
\text { competency framework }\end{array}$ & $\begin{array}{l}\text { Four main domains: clinical domain, } \\
\text { professional domain, managerial domain, } \\
\text { and education and development domain. } \\
\text { These are divided into } 14 \text { different } \\
\text { subdomains }\end{array}$ \\
\hline $\begin{array}{l}\text { Camelo 2012, Brazil } \\
\text { [33] }\end{array}$ & $\begin{array}{l}\text { "Professional Competences } \\
\text { of Nurse to Work in } \\
\text { Intensive Care Units: An } \\
\text { Integrative Review" } \\
\text { Literature review }\end{array}$ & $\begin{array}{l}\text { To identify and analyse } \\
\text { nurses' competences to } \\
\text { work at intensive care units }\end{array}$ & $\begin{array}{l}\text { Eight themes of competence were found: } \\
\text { nursing care management, high-complexity } \\
\text { nursing care delivery, decision-making, } \\
\text { leadership, communication, } \\
\text { continuing/permanent education, human } \\
\text { resource management, and material } \\
\text { resource management }\end{array}$ \\
\hline $\begin{array}{l}\text { Gill et al. 2012, } \\
\text { Australia [34] }\end{array}$ & $\begin{array}{l}\text { "A Review of Critical Care } \\
\text { Nursing Staffing Education } \\
\text { and Practice Standards" } \\
\text { Review }\end{array}$ & $\begin{array}{l}\text { To review the differences } \\
\text { and similarities in critical } \\
\text { care nursing staffing, } \\
\text { education, and practice } \\
\text { standards in the US, } \\
\text { Canada, UK, New Zealand, } \\
\text { and Australia }\end{array}$ & $\begin{array}{l}\text { There is a general consensus about the } \\
\text { importance of optimum staffing by } \\
\text { registered nurses with proportion of those } \\
\text { holding relevant postregistration } \\
\text { qualifications; there is no consistency in } \\
\text { defining the educational preparation for } \\
\text { qualified critical care nurse }\end{array}$ \\
\hline $\begin{array}{l}\text { Hadjibalassi et al. } \\
\text { 2012, Cyprus [35] }\end{array}$ & $\begin{array}{l}\text { "Development of an } \\
\text { Instrument to Determine } \\
\text { Competencies of } \\
\text { Postgraduate ICU Nurses } \\
\text { in Cyprus } \\
\text { Combination of Qualitative } \\
\text { and Quantitative } \\
\text { Approach" }\end{array}$ & $\begin{array}{l}\text { To report the development } \\
\text { of an instrument to } \\
\text { determine what } \\
\text { competencies are expected } \\
\text { of postgraduate critical care } \\
\text { nurses }\end{array}$ & $\begin{array}{l}\text { The final questionnaire includes } 72 \text { items } \\
\text { and has a four-dimensional structure; the } \\
\text { dimensions are (i) leadership/management } \\
\text { and professional development, (ii) } \\
\text { decision-making and management of } \\
\text { emergencies, (iii) provision of care and } \\
\text { professional practice, and (iv) ethical } \\
\text { practice }\end{array}$ \\
\hline $\begin{array}{l}\text { Fullbrook et al. 2012, } \\
\text { Australia [23] }\end{array}$ & $\begin{array}{l}\text { "A Survey of European } \\
\text { Intensive Care Nurses' } \\
\text { Knowledge Levels" } \\
\text { Questionnaire survey }\end{array}$ & $\begin{array}{l}\text { To examine the knowledge } \\
\text { levels of European intensive } \\
\text { care nurses }\end{array}$ & $\begin{array}{l}\text { The overall mean knowledge score was } 66 \% \\
\text { (SD 12); the main factor that contributed to } \\
\text { variance in scores was nurses' length of } \\
\text { intensive care experience; the knowledge } \\
\text { category which scored lowest was } \\
\text { respiration and ventilation }\end{array}$ \\
\hline $\begin{array}{l}\text { Lakanmaa et al. 2012, } \\
\text { Finland [11] }\end{array}$ & $\begin{array}{l}\text { "Competence } \\
\text { Requirements in Intensive } \\
\text { and Critical Care } \\
\text { Nursing-Still in Need of } \\
\text { Definition? A Delphi } \\
\text { Study" Qualitative Delphi } \\
\text { study }\end{array}$ & $\begin{array}{l}\text { To identify competence } \\
\text { requirements }\end{array}$ & $\begin{array}{l}\text { Competence requirements can be divided } \\
\text { into five main domains: knowledge base, } \\
\text { skill base, attitude and value base, nursing } \\
\text { experience base, and personal base of the } \\
\text { nurse }\end{array}$ \\
\hline
\end{tabular}


TABLe 5: Continued.

\begin{tabular}{|c|c|c|}
\hline $\begin{array}{l}\text { Organisation/author, } \\
\text { year, country }\end{array}$ & $\begin{array}{l}\text { Document/title of the } \\
\text { study/method }\end{array}$ & Aim \\
\hline $\begin{array}{l}\text { Critical Care } \\
\text { Networks-National } \\
\text { Nurse Leads 2012, } \\
\text { UK [25] }\end{array}$ & $\begin{array}{l}\text { "National Competency } \\
\text { Framework for Adult } \\
\text { Critical Care Nurses" }\end{array}$ & $\begin{array}{l}\text { The framework is a } \\
\text { collection of the core } \\
\text { clinical competencies that } \\
\text { have been identified as } \\
\text { basic to the effective } \\
\text { performance of adult } \\
\text { critical care nursing }\end{array}$ \\
\hline $\begin{array}{l}\text { O’Leary 2012, USA } \\
\text { [21] }\end{array}$ & $\begin{array}{l}\text { "Comparison of } \\
\text { Self-Assessed Competence } \\
\text { and Experience among } \\
\text { Critical Care Nurses" } \\
\text { Questionnaire survey }\end{array}$ & $\begin{array}{l}\text { To determine the level of } \\
\text { self-assessed nursing } \\
\text { competence and the } \\
\text { relationship with age and } \\
\text { experience in nursing }\end{array}$ \\
\hline $\begin{array}{l}\text { Stewart and Rae } \\
\text { 2013, UK [36] }\end{array}$ & $\begin{array}{l}\text { "Critical Care Nurses' } \\
\text { Understanding of the NHS } \\
\text { Knowledge and Skills } \\
\text { Framework. An } \\
\text { Interpretative } \\
\text { Phenomenological } \\
\text { Analysis" } \\
\text { Qualitative study }\end{array}$ & $\begin{array}{l}\text { To explore critical care } \\
\text { nurses' understanding of } \\
\text { the National Health Service } \\
\text { (NHS) Knowledge and } \\
\text { Skills Framework (KSF) }\end{array}$ \\
\hline
\end{tabular}

Main findings/results

Step 1 competencies should be commenced when a nurse begins in critical care or when he/she has no previous experience of the speciality

Step 2 and 3 competencies should be completed during the period of an academic critical care programme

The Critical Care Competency Framework Content includes several system and additional areas

The nurses "self-assessed level of competence ranged from good to excellent along with an increased frequency of using competencies. The longer the nurses" experience, the greater their self-assessed level of competence

Two superordinate themes of "engagement" and "theory-practice gap" were identified; six subthemes of "fluency," "transparency," "self-assessment," "achieving for whom," "reflection," and "the nursing role" further explained the superordinate themes Challenges identified were primarily concerned with complex language, an unclear process, and the use of reflective and self-assessment skills

There are six standards: (i) nursing education is provided and managed by appropriately qualified staff, (ii) entry requirements for nursing programmes are explicit, fair, and equitable, (iii) the curriculum is developed collaboratively and directed towards providing clinical, educational, and professional preparation to be a qualified nurse, (iv) the opportunity to gain clinical competence in the areas covered by the programme is also provided, (v) nurses are assessed throughout and on completion of the programme, and (vi) theoretical content is offered to provide the nurse with knowledge to assess, plan, manage, document, and analyse the care of the critically ill patient and family

Section 2010, New Zealand [37]

"New Zealand Standards in Care Nursing Education"
The standards provide the framework for curriculum evaluation
Seven standards are provided related to patient monitoring and management for the promotion of optimal physiological balance, comfort, and well-being of the patient, patient and family centeredness care, end-of-life care, patient safety and best practice, collaboration practice, and leadership

The nursing process is used as the framework. Nine standards include activities related to quality of professional practice, professional practice evaluation, education, collegiality, ethics, collaboration, research, resource utilization, and leadership
"AACN Scope and

AACN 2008, USA

[39]
Standards for Acute and

Critical Care Nursing Practice"
To provide an essential professionals in their pursuit of best practice in the critical care environment
To describe a competent level of behaviour in the professional role. The measurement criteria describe how the standards are met 
TABLE 5: Continued.

\begin{tabular}{|c|c|c|c|}
\hline $\begin{array}{l}\text { Organisation/author, } \\
\text { year, country }\end{array}$ & $\begin{array}{l}\text { Document/title of the } \\
\text { study/method }\end{array}$ & Aim & Main findings/results \\
\hline $\begin{array}{l}\text { Ääri et al. 2008, } \\
\text { Finland [40] }\end{array}$ & $\begin{array}{l}\text { "Competence in Intensive } \\
\text { and Critical Care Nursing: } \\
\text { A Literature Review" } \\
\text { Literature review }\end{array}$ & $\begin{array}{l}\text { To define and describe the } \\
\text { concept of competence } \\
\text { in adult intensive care } \\
\text { nursing }\end{array}$ & $\begin{array}{l}\text { Clinical and professional competence in } \\
\text { intensive and critical care nursing can be } \\
\text { defined as a specific knowledge base, skill } \\
\text { base, attitude and value base, and experience } \\
\text { base of intensive and critical care nursing }\end{array}$ \\
\hline $\begin{array}{l}\text { Salonen et al. 2007, } \\
\text { Finland [22] }\end{array}$ & $\begin{array}{l}\text { "Competence Profiles of } \\
\text { Recently Registered Nurses } \\
\text { Working in Intensive and } \\
\text { Emergency Settings" }\end{array}$ & $\begin{array}{l}\text { To describe recently } \\
\text { registered nurses' } \\
\text { perceptions of their } \\
\text { competence level and to } \\
\text { identify factors influencing } \\
\text { these perceptions }\end{array}$ & $\begin{array}{l}\text { Nurses' self-assessed competence level } \\
\text { ranged from moderate to good; a statistically } \\
\text { significant association was seen between } \\
\text { competence level and age, length of current } \\
\text { work experience, and the frequency of using } \\
\text { competencies }\end{array}$ \\
\hline $\begin{array}{l}\text { ACCCN 2006, } \\
\text { Australia [41] }\end{array}$ & $\begin{array}{l}\text { "ACCCN Position } \\
\text { Statement (2006) on the } \\
\text { Provision of Critical Care } \\
\text { Nursing Education" }\end{array}$ & $\begin{array}{l}\text { To outline the } \\
\text { recommendations } \\
\text { regarding the provision of } \\
\text { critical care nursing } \\
\text { education }\end{array}$ & $\begin{array}{l}\text { The recommendations are based on } \\
\text { evidence from research in critical care } \\
\text { nursing or allied fields } \\
\text { In areas where current research-based } \\
\text { evidence is } \\
\text { not available, the recommendations }(16,16 \\
\text { subject areas) are based on the opinion of } \\
\text { expert nurses }\end{array}$ \\
\hline $\begin{array}{l}\text { Lindberg 2006, } \\
\text { Sweden [42] }\end{array}$ & $\begin{array}{l}\text { "Competence in Critical } \\
\text { Care: What It Is and How } \\
\text { to Gain It: A Qualitative } \\
\text { Study from the Staff's Point } \\
\text { of View" } \\
\text { Qualitative interview study }\end{array}$ & $\begin{array}{l}\text { To contribute to the body } \\
\text { of knowledge relating to the } \\
\text { concept of competence }\end{array}$ & $\begin{array}{l}\text { Five different ways of understanding } \\
\text { competence in intensive care were } \\
\text { described: ability to cooperate, being able to } \\
\text { perceive the situation correctly, being aware } \\
\text { of abilities and limitations, being able to act, } \\
\text { and being able to disregard the technology } \\
\text { when needed }\end{array}$ \\
\hline
\end{tabular}

To determine the construct validity of the Australian College of Critical Care Nurses (ACCCN) competency standards as a tool for assessing the clinical practice of specialist level critical care nurses

To inform critical care nursing associations, health care providers, and educational facilities of the development and provision of critical care nursing education

"Position Statement on the Provision of Critical Care

WFCCN 2005 [43] Nursing Education-Declaration of Madrid, 2005"

education

There was no support for the structure for the ACCCN competencies; the elements did not fit statistically uniquely to a single competency. Competency statements also loaded across several domains

Five central principles and 14 recommendation guidelines providing critical care nursing education: health services, educational facilities, and critical care nursing organisations

Nurses reported their overall level of competence as good; they felt most competent in the categories of managing situations, diagnostic functions, and helping role and least competent in ensuring quality category

The greater the self-assessed level of competence,

the higher the frequency of using of competencies; correlations between both age and length of work experience and the self-assessed overall level of competence were positive 


\section{Conflict of Interests}

The authors have no conflict of interests.

\section{Authors' Contribution}

(1) The conception and design of the study, or acquisition of data, or analysis and interpretation of data were performed by R.-L. Lakanmaa, M. Ritmala-Castrén, T. Suominen, H. Leino-Kilpi, and T. Vahlberg. (2) Drafting the paper or revising it critically for important intellectual content was done by R.-L. Lakanmaa, M. Ritmala-Castrén, T. Suominen, H. Leino-Kilpi, and T. Vahlberg. (3) Final approval of the version to be submitted was performed by R.-L. Lakanmaa, M. Ritmala-Castrén, T. Suominen, H. Leino-Kilpi, and T. Vahlberg. All authors have approved the final paper and acknowledge that all those entitled to authorship are listed as authors.

\section{Acknowledgments}

All ICU nurses and contact persons from university hospitals in Finland who participated in this study are gratefully acknowledged. Mrs. Anna Vuolteenaho is also acknowledged for her expertise in the English language. The Finnish PostGraduate School in Nursing Science financed this project.

\section{References}

[1] M. Ritmala-Castrén, H. Lundgren-Laine, and L.-M. Murtola, "Aikuispotilaiden tehohoitopalvelut Suomessa vuonna 2012," Tehohoito, vol. 32, no. 1, pp. 18-23, 2014.

[2] M. Reinikainen, Hospital mortality of intensive care patients in Finland. Insights into prognostic factors and measuring outcomes [Ph.D. thesis], Department of Medicine, University of Eastern Finland, Joensuu, Finland, 2012, http://epublications .uef.fi/pub/urn_isbn_978-952-61-0719-6/.

[3] EfCCNa, "Position Statement on workforce requirements within," Position Statement on workforce requirements within European Critical Care Nursing, 2007, http://www.efccna.org/downloads/ Position\%20Statement\%20Workforce\%20EfCCNa\%202007.pdf.

[4] EfCCNa, EfCCNa Competencies for European Critical Care Nurses, 2013, http://www.efccna.org/images/stories/publication/competencies_cc.pdf.

[5] M. K. Robnett, "Critical care nursing: workforce issues and potential solutions," Critical Care Medicine, vol. 34, no. 3, pp. S25-S31, 2006.

[6] E. West, N. Mays, A. M. Rafferty, K. Rowan, and C. Sanderson, "Nursing resources and patient outcomes in intensive care: a systematic review of the literature," International Journal of Nursing Studies, vol. 46, no. 7, pp. 993-1011, 2009.

[7] D. A. Penoyer, "Nurse staffing and patient outcomes in critical care: a concise review," Critical Care Medicine, vol. 38, no. 7, pp. 1521-1528, 2010.

[8] D. Kendall-Gallagher and M. A. Blegen, "Competence and certification of registered nurses and safety of patients in intensive care units," American Journal of Critical Care, vol. 18, no. 2, pp. 106-113, 2009.
[9] S. D. Person, J. J. Allison, C. I. Kiefe et al., "Nurse staffing and mortality for medicare patients with acute myocardial infarction," Medical Care, vol. 42, no. 1, pp. 4-12, 2004.

[10] A. Rischbieth, "Matching nurse skill with patient acuity in the intensive care units: a risk management mandate," Journal of Nursing Management, vol. 14, no. 5, pp. 397-404, 2006.

[11] R.-L. Lakanmaa, T. Suominen, J. Perttilä, P. Puukka, and H. Leino-Kilpi, "Competence requirements in intensive and critical care nursing-still in need of definition? A Delphi study," Intensive and Critical Care Nursing, vol. 28, no. 6, pp. 329-336, 2012.

[12] M. Relf and R. Kaplow, "Critical care nursing practice: an integration of caring, competence, and commitment to excellence," in Critical Care Nursing. A Holistic Approach, M. P. Gonce, D. K. Fontaine, C. M. Hudak, and B. M. Gallo, Eds., pp. 311, Lippincott Williams \& Wilkins, Philadelphia, Pa, USA, 8th edition, 2006.

[13] WHO, WHO Europe Critical Care Nursing Curriculum, 2003, http://www.euro.who.int/__data/assets/pdf_file/0017/102266/ e81552.pdf.

[14] Ministry of Education, The National Framework for Qualifications and Other Learning, 2009, http://www.minedu.fi/OPM/ Julkaisut/2009/Tutkintojen_kansallinen_viitekehys.html?lang= fi\&extra_locale $=$ fi.

[15] European Communities, Education and Culture. The European qualification framework for lifelong learning (EQF), 2008, https://ec.europa.eu/ploteus/sites/eac-eqf/files/leaflet_en.pdf.

[16] M. Flinkman, Young registered nurses intent to leave the profession in Finland-a mixed method study, Department of Nursing Science, University of Turku, Turku, Finland, 2014, http://www.doria.fi/bitstream/handle/10024/95711/AnnalesD1107Flinkman.pdf? sequence $=2$.

[17] ACCCN, Position Statement (2006) on the Provision of Critical Care Nursing Education, 2006, https://www.acccn.com.au/ documents/item/19.

[18] EfCCNa, "Position Statement on Post-registration Critical Care Nursing Education within Europe," 2004, http://www.efccna.org/ downloads/Position\%20statement\%20on\%20education\%20EfCCNa .pdf.

[19] R.-L. Lakanmaa, Competence in intensive and critical care nursing-development of basic assessment scale for graduating nursing students [dissertation], Department of Nursing Science, University of Turku, 2012, Annales Universitatis Turkuensis. SER D 1014. Medica-Odontologica, http://www.doria.fi/bitstream/ handle/10024/76824/Annales\%20D\%201014\%20Lakanmaa\%20DISS .pdf.

[20] R. Meretoja, H. Leino-Kilpi, and A.-M. Kaira, "Comparison of nurse competence in different hospital work environments," Journal of Nursing Management, vol. 12, no. 5, pp. 329-336, 2004.

[21] J. O'Leary, "Comparison of self-assessed competence and experience among critical care nurses," Journal of Nursing Management, vol. 20, no. 5, pp. 607-614, 2012.

[22] A. H. Salonen, M. Kaunonen, R. Meretoja, and M.-T. Tarkka, "Competence profiles of recently registered nurses working in intensive and emergency settings," Journal of Nursing Management, vol. 15, no. 8, pp. 792-800, 2007.

[23] P. Fulbrook, J. W. Albarran, B. Baktoft, and B. Sidebottom, "A survey of European intensive care nurses' knowledge levels," International Journal of Nursing Studies, vol. 49, no. 2, pp. 191200, 2012.

[24] R.-L. Lakanmaa, T. Suominen, J. Perttilä, M. Ritmala-Castrén, T. Vahlberg, and H. Leino-Kilpi, "Basic competence in intensive 
and critical care nursing: development and psychometric testing of a competence scale," Journal of Clinical Nursing, vol. 23, no. 5-6, pp. 799-810, 2014.

[25] Critical Care Networks-National Nurse Leads, "National Competency Framework for Adult Critical Care Nurses," 2012, http://www.cc3n.org.uk/competency-framework/4577977310.

[26] F. J. Gill, G. D. Leslie, C. Grech, D. Boldy, and J. M. Latour, "Development of Australian clinical practice outcome standards for graduates of critical care nurse education," Journal of Clinical Nursing, vol. 24, no. 3-4, pp. 486-499, 2015.

[27] J. Toth, The Basic Knowledge Assessment Tool (BKAT), 2014, http://www.bkat-toth.org/index.html.

[28] European Comission, Ethics for Researchers. Facilitating Research Excellence in FP7, Office for Official Publications of the European Communities, Luxembourg City, Luxembourgh, 2013, http://ec.europa.eu/research/participants/data/ref/fp7/ 89888/ethics-for-researchers_en.pdf.

[29] TENK, Hyvä tieteellinen käytäntö ja sen loukkausepäilyjen käsitteleminen Suomessa, 2012, http://www.tenk.fi/sites/tenk.fi/ files/htk_ohje_verkko14112012.pdf.

[30] S.-L. Varjus, H. Leino-Kilpi, and T. Suominen, "Professional autonomy of nurses in hospital settings-a review of the literature," Scandinavian Journal of Caring Sciences, vol. 25, no. 1, pp. 201-207, 2011.

[31] W. Chaboyer, D. Chamberlain, K. Hewson-Conroy et al., "Safety culture in Australian intensive care units: establishing a baseline for quality improvement," American Journal of Critical Care, vol. 22, no. 2, pp. 93-102, 2013.

[32] M. J. Fisher, A. P. Marshall, and T. S. Kendrick, "Competency standards for critical care nurses: do they measure up?" Australian Journal of Advanced Nursing, vol. 22, no. 4, pp. 32-39, 2005.

[33] S. H. H. Camelo, "Professional competences of nurse to work in intensive care units: an integrative review," Revista LatinoAmericana de Enfermagem, vol. 20, no. 1, pp. 192-200, 2012.

[34] F. J. Gill, G. D. Leslie, C. Grech, and J. M. Latour, "A review of critical care nursing staffing, education and practice standards," Australian Critical Care, vol. 25, no. 4, pp. 224-237, 2012.

[35] M. Hadjibalassi, E. Papastavrou, E. Lambrinou et al., "Development of an instrument to determine competencies of postgraduate ICU nurses in Cyprus," Nursing in Critical Care, vol. 17, no. 5, pp. 255-264, 2012.

[36] L. F. M. Stewart and A. M. Rae, "Critical care nurses' understanding of the NHS knowledge and skills framework. An interpretative phenomenological analysis," Nursing in Critical Care, vol. 18, no. 1, pp. 23-31, 2013.

[37] Critical Care Nurses' Section, New Zealand Standards in Critical Care Nursing Education, New Zealand College of Critical Care Nurses, Wellington, New Zealand, 4th edition, 2010.

[38] CACCN, Standards for Critical Care Nursing Practice, Canadian Association of Critical Care Nurses (CACCN), Ontario, Canada, 2009.

[39] AACN, AACN Scope and Standards for Acute and Critical Care Nursing Practice, American Association of Critical-Care Nurses (AACN), 2008.

[40] R.-L. Ääri, S. Tarja, and L.-K. Helena, "Competence in intensive and critical care nursing: a literature review," Intensive and Critical Care Nursing, vol. 24, no. 2, pp. 78-89, 2008.

[41] ACCCN, ACCCN Position Statement (2006) on the Provision of Critical Care Nursing Education, Australian College of Critical Care Nurses (ACCCN), Surrey Hills, Australia, 2006.
[42] E. Lindberg, "Competence in critical care: what it is and how to gain it: a qualitative study from the staff's point of view," Dimensions of Critical Care Nursing, vol. 25, no. 2, pp. 77-81, 2006.

[43] WFCCN, Position Statement on the Provision of Critical Care Nursing Education-Declaration of Madrid, 2005, World Federation of Critical Care Nurses (WFCCN), 2005. 


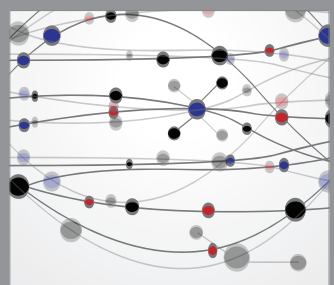

The Scientific World Journal
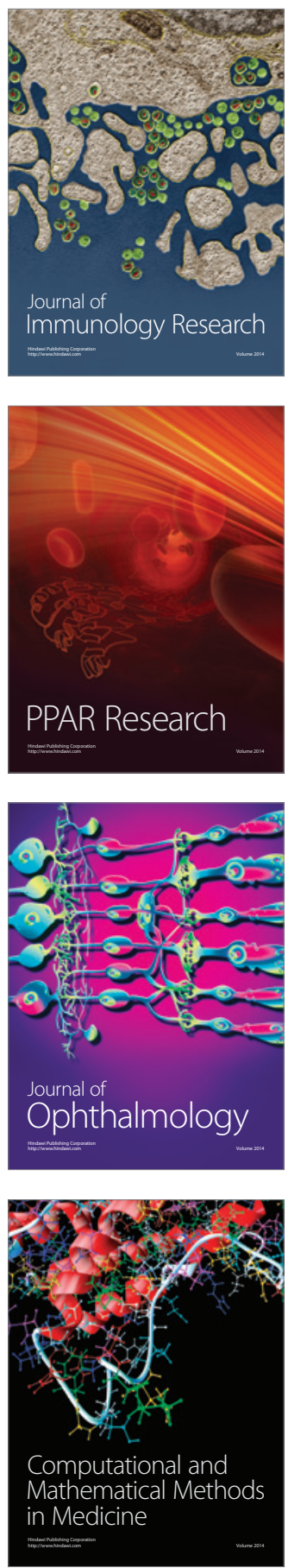

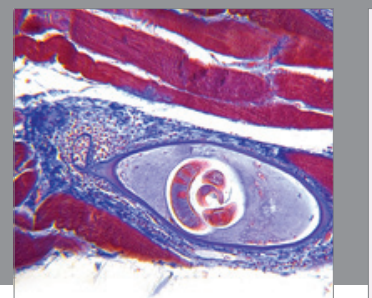

Gastroenterology

Research and Practice
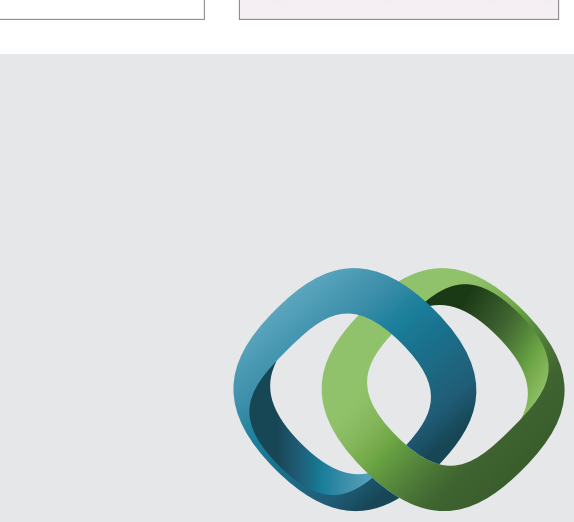

\section{Hindawi}

Submit your manuscripts at

http://www.hindawi.com
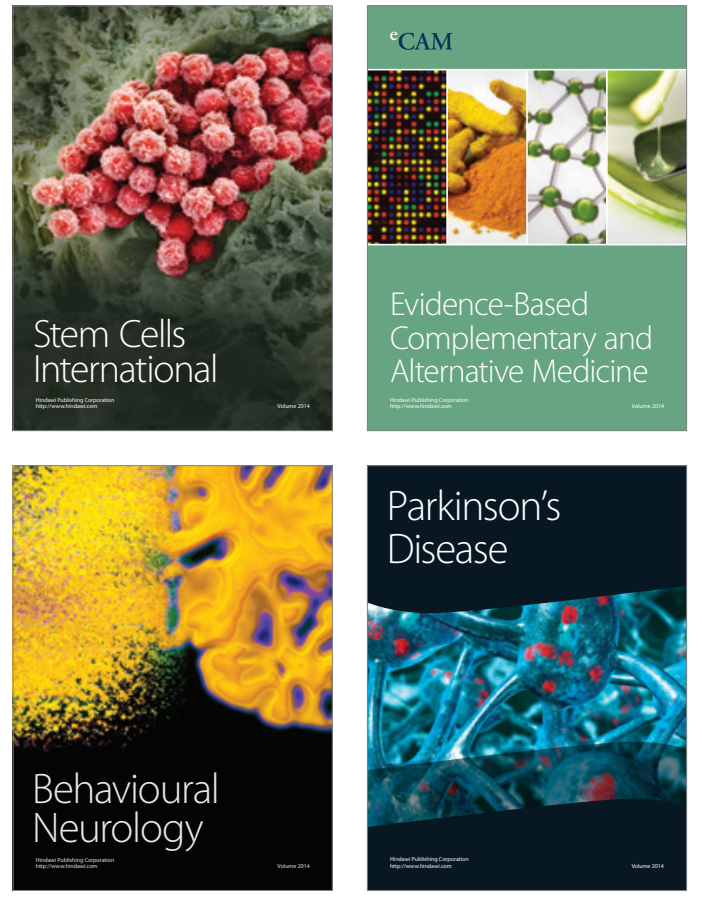
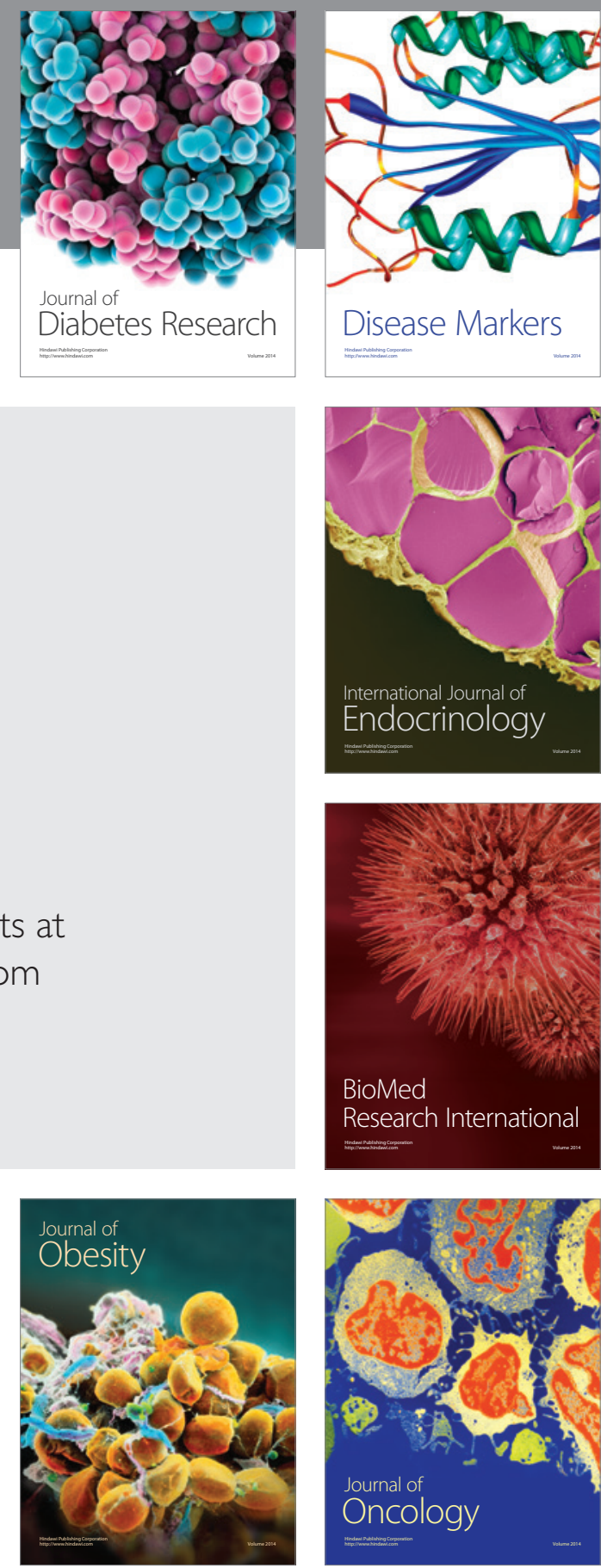

Disease Markers
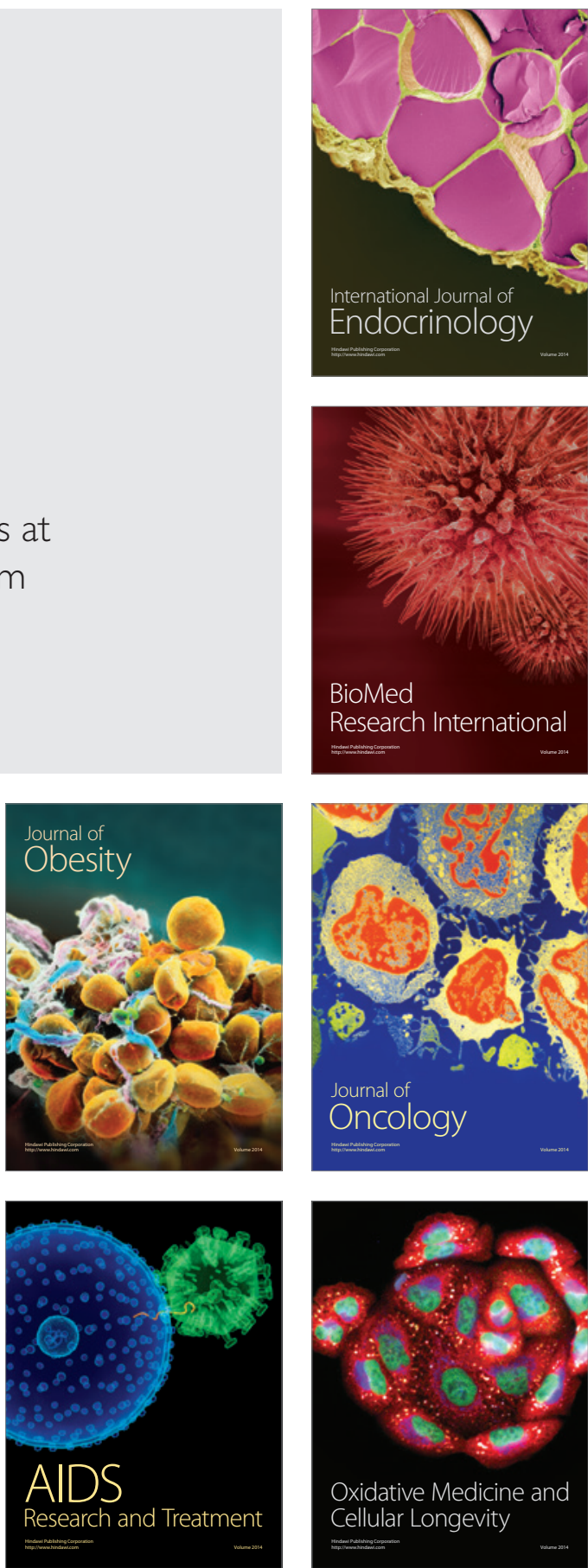